\title{
List of Abbreviations for Works by Jean-Luc Nancy
}

A Adoration: The Deconstruction of Christianity II, trans. John McKeane, New York: Fordham University Press, 2013.

'A' 'A-religion', trans. Julia Borossa, Fournal of European Studies 34.1 (2004): 14-18.

AF After Fukushima: The Equivalence of Catastrophes, trans. Charlotte Mandell, New York: Fordham University Press, 2014.

All Allitérations. Conversations sur la danse, with Mathilde Monnier, Paris: Galilée, 2005.

BP The Birth to Presence, trans. Brian Holmes et al., Stanford: Stanford University Press, 1993.

BSP Being Singular Plural, trans. Anne E. O'Byrne and Robert D. Richardson, Stanford: Stanford University Press, 2000.

C Corpus, trans. Richard A. Rand, New York: Fordham University Press, 2008.

'C' 'La Comparution/The Compearance: From the Existence of Communism to the Community of Existence', trans. Tracy B. Strong, Political Theory 20.3 (1992): 371-98.

'CC' 'The Confronted Community', trans. Amanda MacDonald, Postcolonial Studies 6.1 (2003): 23-36.

CI L'impératif catégorique, Paris: Flammarion, 1983.

CII Corpus II: Writings on Sexuality, trans. Anne O'Byrne, New York: Fordham University Press, 2013.

'CP' 'The Calculation of the Poet', trans. Simon Sparks, in Aris Fioretos (ed.), The Solid Letter: Readings of Friedrich Hölderlin, Stanford: Stanford University Press, 2000, pp. 44-73.

'CTW' 'Communism, the Word', in Costas Douzinas and Slavoj Žižek (eds), The Idea of Communism, London: Verso, 2010, pp. 146-53.

$\mathrm{CW}$ The Creation of the World or Globalization, trans. François Raffoul and David Pettigrew, New York: SUNY Press, 2007.

D-E Dis-Enclosure. The Deconstruction of Christianity, trans. Bettina Bergo, Gabriel Malenfant and Michael B. Smith, New York: Fordham University Press, 2008.

'DEG' 'On Dis-enclosure and Its Gesture, Adoration: A Concluding Dialogue with Jean-Luc Nancy', trans. John McKeane, in Alena Alexandrova, Ignaas Devisch, Laurens Ten Kate and Aukje van 
Rooden (eds), Re-treating Religion: Deconstructing Christianity with Fean-Luc Nancy, New York: Fordham University Press, 2012, pp. 304-43.

DS The Discourse of the Syncope: Logodaedalus, trans. Saul Anton, Stanford: Stanford University Press, 2008.

'E' 'Entretien avec Jean-Luc Nancy', with Véronique Fabbri, Rue Descartes 44.2 (2004): 62-79.

EF The Experience of Freedom, trans. Bridget McDonald, Stanford: Stanford University Press, 1993.

ES Ego sum, Paris: Flammarion, 1979.

EvF L'Évidence du film: Abbas Kiarostami, Brussels: Yves Gevaert, 2001.

'FI' 'Finite and Infinite Democracy', in Giorgio Agamben, Alain Badiou, Daniel Bensaid, Wendy Brown, Jean-Luc Nancy, Jacques Rancière, Democracy in What State?, New York: Columbia University Press, 2012, pp. 58-75.

'FIL' 'From the Imperative to Law', in B. C. Hutchens (ed.), Fean Luc Nancy: Fustice, Legality and World, London: Continuum, 2012, pp. 11-18.

FS The Fall of Sleep, trans. Charlotte Mandell, New York: Fordham University Press, 2009.

FT A Finite Thinking, ed. Simon Sparks, Stanford: Stanford University Press, 2003.

GI The Ground of the Image, trans. Jeff Fort, New York: Fordham University Press, 2005.

G7 God, Fustice, Love, Beauty: Four Little Dialogues, trans. Sarah Clift, New York: Fordham University Press, 2011.

GT The Gravity of Thought, trans. François Raffoul and Gregory Recco, New York: Humanities Press, 1998.

$H \quad H e g e l:$ The Restlessness of the Negative, trans. Jason Smith and Steven Miller, Minneapolis: University of Minnesota Press, 2002.

'HC' 'Hors colloque', in Gisèle Berkman and Danielle Cohen-Levinas (eds), Figures du dehors: autour de Jean-Luc Nancy, Nantes: Cécile Défaut, 2012, pp. 517-38.

I Identity: Fragments, Frankness, trans. François Raffoul, New York: Fordham University Press, 2014.

IC The Inoperative Community, ed. Peter Connor, Minneapolis: University of Minnesota Press, 1993.

I La jouissance, with Adèle Van Reeth, Paris: Plon, 2014.

L Listening, trans. Charlotte Mandell, New York: Fordham University Press, 2007. 
LA The Literary Absolute, with Philippe Lacoue-Labarthe, trans. Philip Barnard and Cheryl Leser, Albany, NY: SUNY Press, 1988.

'LC' 'Love and Community: A Round-table Discussion with JeanLuc Nancy, Avital Ronell and Wolfgang Schirmacher', August 2001, available at <http://www.egs.edu/faculty/jean-lucnancy/articles/love-and-community $>$ (last accessed 12 March 2015).

M The Muses, trans. Peggy Kamuf, Stanford: Stanford University Press, 1996.

MII Multiple Arts: The Muses II, trans. Simon Sparks, Stanford: Stanford University Press, 2006.

'NM' 'The Nazi Myth', with Philippe Lacoue-Labarthe, trans. Brian Holmes, Critical Inquiry 16.2 (1990): 291-312.

NT Noli Me Tangere: On the Raising of the Body, trans. Pascale-Anne Brault, Sarah Clift and Michael Naas, New York: Fordham University Press, 2008.

'OBC' 'Of Being-in-Common', trans. James Creech, in the Miami Theory Collective (ed.), Community at Loose Ends, Minneapolis: University of Minnesota Press, 1991.

'OP’ “'Our Probity!” On Truth in the Moral Sense in Nietzsche', trans. Peter Connor, in Laurence A. Rickels (ed.), Looking After Nietzsche, Albany, NY: SUNY Press, 1990, pp. 67-88.

PC Philosophical Chronicles, trans. Franson Manjali, New York: Fordham University Press, 2008.

PD La pensée dérobée, Paris: Galilée, 2001.

PM La possibilité d'un monde - Dialogue avec Pierre-Philippe Jandin, Paris: Les petits Platons, 2013.

PP Le poids d'une pensée, l'approche, Strasbourg: Le Phocide, 2008.

PS ' (le peuple souverain s'avance)', in Marie-Louise Mallet (ed.), La démocratie à venir: autour de Facques Derrida, Paris: Galilée, 2004, pp. 341-59.

RP Retreating the Political, with Philippe Lacoue-Labarthe, ed. Simon Sparks, London and New York: Routledge, 1997.

'SDC' 'The Self-Deconstruction of Christianity: An Open Discussion with Jean-Luc Nancy', August 2000, available at <http://www. egs.edu/faculty/jean-luc-nancy/articles/the-self-deconstruction-of-christianity > (last accessed 12 March 2015).

SR The Speculative Remark (One of Hegel's Bons Mots), trans. Céline Surprenant, Stanford: Stanford University Press, 2001.

$S W \quad$ The Sense of the World, trans. Jeffrey S. Librett, Minneapolis: University of Minnesota Press, 2003. 
TD The Truth of Democracy, trans. Pascale-Anne Brault and Michael Naas, New York: Fordham University Press, 2010.

$T L \quad$ The Title of the Letter, with Philippe Lacoue-Labarthe, trans. François Raffoul and David Pettigrew, Albany, NY: SUNY Press, 1992.

WTW What's These Worlds Coming To?, with Aurélien Barrau, trans. Flor Méchain and Travis Holloway, New York: Fordham University Press, 2014. 